\title{
Acceptance Factors and Current Level of Use of Web 2.0 Technologies for Learning in Higher Education: a Case Study of Two Countries
}

\author{
Razep Echeng \\ University of the West of Scotland \\ Paisley, United Kingdom
}

\author{
Abel Usoro \\ University of the West of Scotland \\ Paisley, United Kingdom
}

\begin{abstract}
The use of Web 2.0 technology tools or social media in educational context is being emphasized in recent times in different parts of the world and this has brought about a significant increase in the number of educational institutions who are aware of their usefulness when either implementing them as a separate system or incorporating them into their learning management systems. However, there is little research on the acceptance and how much these tools are currently being used for learning hence the need for more empirical studies to investigate factors that would influence acceptance and increase the use of these technologies. The study developed hypotheses and a research model which was operationalized into a questionnaire administered to academics and students in Scotland and Nigeria. 317 responses were received from Nigeria and 279 from Scotland. Analysed data was used to validate the research model that is aimed at explaining acceptance and present level of use of Web 2.0 technology tools in learning environments.
\end{abstract}

Keywords-Web 2.0 technologies; acceptance factors; adoption for learning; collaboration; participation; Nigerian higher education; Scotland

\section{INTRODUCTION}

Acceptance of technology has long been a challenging issue in information systems research [1]. Understanding the reason why people accept or reject technology is very crucial because it serves as a guide to investors, manufacturers, institutions and their managers. Much research has used technology acceptance models (TAM) to measure acceptance of technology [2][3][4][5]. Whereas some research exist in developed countries on acceptance of Web 2.0 tools in learning, not much of such empirical studies has been done in developing economies. Neither has there been a comparative study of these economies. Hence, this study investigates Nigeria and Scotland as well as compares these two countries in terms of the factors of the model such as perceived usefulness, performance expectancy, motivation, ease of use, attitude, behaviour and actual use. The investigation also endeavours to ascertain how the model can be used to explain the acceptance and the use of Web 2.0 social network technology tools in teaching and learning in higher institutions of developed and developing communities. The rest of this paper presents literature review, method, data analyses, discussion, conclusions, implications and areas for future study.

\section{LITERATURE REVIEW}

\section{A. Nigeria and Scotland}

Few empirical studies exist in Nigeria that examined the use of Web 2.0 in learning [6][7]. These researches were interested in the use of Web 2.0 by librarians, academics and students in Nigeria. They found the use of these tools for academic purpose lacking and identified five major problems: personality characteristics, motivation, lack of facilities and lack of computer expertise. They also suggested more research into how these technologies can be adopted for teaching and learning.

Little research has been done on the acceptance of Web 2.0 tools in higher institutions in developed countries [8] and their research inferred that subjective norm of students affect their acceptance, and little has been researched on users' acceptance of Web 2.0 technology tools in learning in Scotland as found in some other developed communities [9][10], hence this research is a comparative study that seeks to bring together factors that influence acceptance and use of Web 2.0 technology tools in learning in order to understand the key factors that could be associated with adoption in these two educational communities.

\section{B. Challenges of Adoption of Web 2.0 in Education}

Literature has documented the challenge of getting students and educators to adopt Web 2.0 tools for educational purposes [11]. Some research explained that the limited adoption is due to lack of understanding of the behaviour of users thereby shifting focus from what users want to what is technologically achievable [12]. Though innovative educators appreciate and use Web 2.0 technologies, others are afraid that these technologies would disrupt young people's engagement with "traditional" education [13[12]. These challenges and debates on them have been noticed in higher education of developed economies [11]. However, these technologies are potentially useful in learning activities.

\section{Potential of Web 2.0 technology tools}

Over the past five to six years, there has been a significant increase in research on educational usefulness and potentials of Web 2.0 [14][15][16]. Most of them have shown that Web 2.0 social network tools can enhance participation, collaboration and interaction in learning. They enable social 
networking site users who are mostly young people to create profiles and build personal networks that connect them to each other for a variety of professional and personal reasons. However, there is still the problem of acceptance and use for academic purposes by both students and educators [17][11] and this calls for investigation on constructs that influence such acceptance and use.

\section{User Acceptance}

User acceptance is exhibited in the willingness of a user or group of users to employ information technology tools for the tasks that they are designed to support. The acceptance of technology has been a challenging issue in information systems research for a long time and researchers have studied a range of issues related to technology acceptance, from individual user characteristics such as cognitive style to internal beliefs and their impact on user's behaviour. It is crucial to understand the reason why people accept or reject technology, because it can serve as a guide to investors, manufacturers, and institutions and for managerial intervention.

Existing research on user acceptance has produced a variety of explanatory and predictive models $[18][2][4][8][20][11]$. However, these models suggest different and, sometimes, conflicting sets of predictor variables. Ajjan's [8] study used the theory of planned behaviour and his findings inferred that subjective norm of students is a key factor that affects their acceptance whereas Armitage and Cornor [19] studied 185 researches that used the theory of planned behaviour (TPB) from 1980 until 1997 and found that subjective norm was a weak variable for predicting behavioural intention. Hence, the need to review other popularly used technology acceptance models in order to understand the major constructs that could contribute to acceptance and use of Web 2.0 technology in learning.

\section{E. Technology Acceptance Models}

Literature review revealed three widely used models of acceptance of technology and these are: theory of reasoned action [18]; technology acceptance model [2]; and unified theory of acceptance and use of technology [4]. Acceptance of technology has been studied in different contexts, but there is limited research on acceptances of Web 2.0 tools in teaching and learning in higher institutions [8] [20] hence, this research developed hypotheses to test acceptance of Web 2.0 technology tools in learning and to answer to the research question which is: What are the factors that would relate to acceptance and use of Web 2.0 tools for learning?

\section{HYPOTHESES DEVELOPMENT}

A selection of constructs was made from three technology acceptance models that support learning: theory of reasoned action [18]; technology acceptance model [2]; and unified theory of acceptance and use of technology [4]. These constructs are: motivation to use, social factor, facilitating conditions, performance expectancy, ease of use and perceived usefulness. This selection was guided by the preliminary interviews with five ICT directors, five lecturers and 16 students in five Nigerian Universities and one university in Scotland.
Fifteen semi structured questions were used to investigate the situation on learning with Web 2.0 technology tools and the possible motivating factors that could be used to enhance the use of these tools in learning. These interviews were analyzed using NVIVO tag cloud in order to retrieve text that were mostly used by the respondents and the clustering cooccurrence or non-occurrence to determine important constructs to be included [21]. This was done to support the inclusion of constructs from the three models and also this analysis suggested the addition of a new construct (prior knowledge) in the hypothesis development. The hypotheses are presented in the rest of this section.

\section{A. Perceived usefulness (PU)}

Perceived usefulness is the belief that the use of technology will improve and progress the work or learning activity of an individual or an organization. Research by Davis et. al.[2] and Venkatesh et. al [4] found that perceived usefulness affects technology acceptance. This research is to examine the effect of perceived usefulness with regards to Web 2.0 technologies for learning with the hypothesis:

$\mathrm{H}_{1}$ : There is a positive relationship between perceived usefulness and behavioural intention to adopt Web 2.0 technologies in learning.

\section{B. Social Factor (SF)}

Social factor in this context comes from the impact of social presence on individual behaviour. This could be communication and interaction with students and lecturers which may result in interpersonal agreements that affect behaviour of individuals in a group [23][24][25][8]. This factor was included in Davis et. al.'s [2] Model as an external factor, which they argued may influence technology acceptance. This variable is also included in UTAUT. This research seeks to validate this argument when considering Web 2.0 technologies acceptance for learning. Therefore:

$\mathrm{H}_{2}$ : Social factor has a positive relationship with behavioural intention to accept Web 2.0 technologies for learning.

\section{Prior Knowledge (PK)}

Prior knowledge can be described as knowledge of a set of circumstances gained in the past sufficient to make actions based on those circumstances. It is often helpful and very useful in learning environments [27][28]. This knowledge or experience could positively relate to acceptance of Web 2.0 technologies for learning, hence the following hypotheses:

\section{$\mathrm{H}_{3}$ : Prior knowledge has a positive relationship with behavioural intention to adopt Web 2.0 technologies for learning.}

\section{Facilitating conditions (FC)}

The access to internet facilities, the availability of good internet signals and the cost of broadband can be regarded as facilitating conditions for the use of Web 2.0 technologies for learning. Therefore, they may be related to the use of Web 2.0 technologies in higher education. Thus, it can be hypothesized that: 
$\mathrm{H}_{4}$ : There is a positive relationship between facilitating conditions and behavioural intention to use Web 2.0 technologies in learning.

\section{E. Perceived Ease of use (PEOU)}

Perceived ease of use is the degree to which an individual believes that the use of technology will be without much effort, but will help to achieve much in a short time [2][26]. This has been used to predict acceptance of technology [2], and this research suggests that perceived ease of use should explain acceptance of Web 2.0 technology tools for higher education, hence the hypothesis:

$\mathrm{H}_{5}$ : There is a positive relationship between perceived ease of use and behavioural intention to adopt Web 2.0 technology tools in learning.

\section{F. Performance Expectancy (PE)}

Performance expectancy is the degree to which an individual or group of people expect to be proficient in their work or education when they are using technology. Ajjan and Harshone's [8] research found this variable as promoting technology acceptance. To investigate this finding in the case of Web 2.0 in learning in higher education, we used the hypothesis:

$\mathrm{H}_{6}$ : There is a positive relationship between performance expectancy and behavioural intention to use Web 2.0 technologies in learning.

\section{G. Motivation to use (MTU)}

Motivation in this context involves emotional support, internal or external support that stirs up a learner or gives the desire to act. Motivation can facilitate or hinder change in a learner [18][28][29]. Intrinsic and extrinsic motivation develops personal behaviour which can in turn affect evaluation of choice, goals and achievements. Thus, motivation to use Web 2.0 technology tools for learning is likely to relate to the attitude of the learners, and it should also be related to behavioural intention.

$\mathrm{H}_{7}$ : There is a positive relationship between motivation and intention to use Web 2.0 technologies for learning.

\section{H. Behavioural intention (BI)}

Ajzen and Fishbein [18] argued that a person's exhibition of a specific behaviour is determined by their behavioural intention. Behavioural intention to use Web 2.0 technology can relate with actual use. Thus the hypothesis:

$\mathrm{H}_{8}$ : Behavioural intention has a positive relationship with actual use of Web 2.0 technologies for learning.

A conceptual model was developed from the hypotheses that have been presented in this section (see Figure 1)

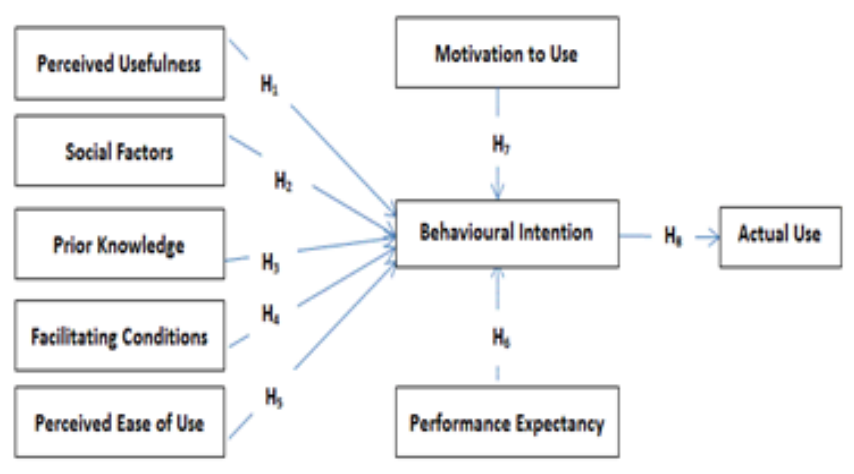

Fig. 1. Conceptual model

\section{METHOD}

The nature of the research question and focus which are on the acceptance of Web 2.0 technologies guided the method adopted. The literature also revealed that most researchers approach similar studies using quantitative research [2][8]. This research operationalized the constructs (see Table 1) into a questionnaire to collect data that would measure the eight constructs in the model.

The questionnaire was divided into three parts: the first part measured students' level of satisfaction in learning and facilities available for teaching and learning; the second part measured the eight constructs in the research model (attitude to use, actual use, perceived usefulness, perceived ease of use, social factor, acceptance and performance. Then the third part investigated demographics (age, gender, educational level, faculty, having personal computer, and having internet access). Items were measured using 5 and 7 point Likert scales with 19 questions. All items in the questionnaire were adapted from earlier and similar research to suit this study [2][8].

\section{A. Content Validation}

The questions had strong theoretical basis and besides they were validated by allowing prospective participants to answer them in order to check whether the questions were understandable and answerable. The questionnaire was amended based on comments from these respondents [30].

\section{B. Participants}

Questionnaire was sent online to students and lecturers in one university in Scotland and participation was voluntary. 279 (78 lecturers and 201 students) responded. The Nigeria questionnaire was administered by lecturers and the researcher who visited five Institutions and collected 317 usable data from participants. Five universities were selected due to differences in Nigerian educational system. 
Table I. QUESTIONNAIRE AND CONSTRUCTS

\begin{tabular}{|c|c|c|c|}
\hline \multicolumn{2}{|l|}{ Constructs } & Questions & $\begin{array}{l}\text { Question } \\
\text { No. }\end{array}$ \\
\hline \multicolumn{2}{|c|}{ Perceived ease of use } & $\begin{array}{l}\text { How easy do you find using these Web } 2.0 \text { tools (listed in question } 6 \text { ) to } \\
\text { obtain the resources you need for your studies? }\end{array}$ & 7 \\
\hline \multirow{2}{*}{\multicolumn{2}{|c|}{ Perceived usefulness }} & $\begin{array}{l}\text { To what extent do you agree that Web } 2.0 \text { tools would speed up } \\
\text { acquisition of knowledge? }\end{array}$ & 12 \\
\hline & & $\begin{array}{l}\text { To what extent do you agree that Web } 2.0 \text { tools will encourage active } \\
\text { participation in learning? }\end{array}$ & 13 \\
\hline \multicolumn{2}{|l|}{ Actual use } & How often do you use Web 2.0 tools for academic purposes per week? & 8 \\
\hline \multicolumn{2}{|l|}{ Social } & $\begin{array}{l}\text { To what extent do you agree that the social part of e-learning platforms } \\
\text { (e.g. Module and Blackboard) motivates learner to achieve learning } \\
\text { objectives? }\end{array}$ & $10 \mathrm{~b}$ \\
\hline \multicolumn{2}{|l|}{ Motivation } & $\begin{array}{l}\text { E-learning platforms enable you to send mails, download course } \\
\text { materials upload assignments, read announcements, access the library } \\
\text { material and discuss with other students, professionals and your } \\
\text { lecturers. To what extent do you think such systems would motivate you } \\
\text { to achieve your learning objectives? }\end{array}$ & $10 \mathrm{a}$ \\
\hline \multicolumn{2}{|c|}{ Facilitating condition } & $\begin{array}{l}\text { Regarding facilities available for learning and teaching in the university, } \\
\text { how satisfied are you? Add any comments regarding conditions } \\
\text { necessary to facilitate Web } 2.0 \text { in in learning. }\end{array}$ & 4 \\
\hline \multicolumn{2}{|c|}{ Performance Expectancy } & $\begin{array}{l}\text { To what extent do you agree that the use of Web } 2.0 \text { technologies for } \\
\text { learning will help to improve performance? }\end{array}$ & 14 \\
\hline \multicolumn{2}{|l|}{ Prior knowledge } & $\begin{array}{l}\text { How often do you use Web } 2.0 \text { tools (e.g. blogs, Wikis, twitter) for } \\
\text { social purposes per week? }\end{array}$ & 6 \\
\hline \multicolumn{2}{|c|}{ Behaviour intention } & $\begin{array}{l}\text { To what extent do you agree that social computing should be adopted in } \\
\text { higher education and training for sharing of knowledge and information? }\end{array}$ & 11 \\
\hline \multirow[t]{4}{*}{ Demographics } & Gender & What is your gender? & 16 \\
\hline & Status & Are you a student or lecturer? & 1 \\
\hline & Field & What is your field? & 19 \\
\hline & Age bracket & What is your age bracket? & 17 \\
\hline
\end{tabular}

\section{DATA ANALYSIS}

This study adapted the quantitative data analysis. Descriptive analysis with frequency tables and histograms was carried out to describe the general responses of each question. The model was tested for general validity.

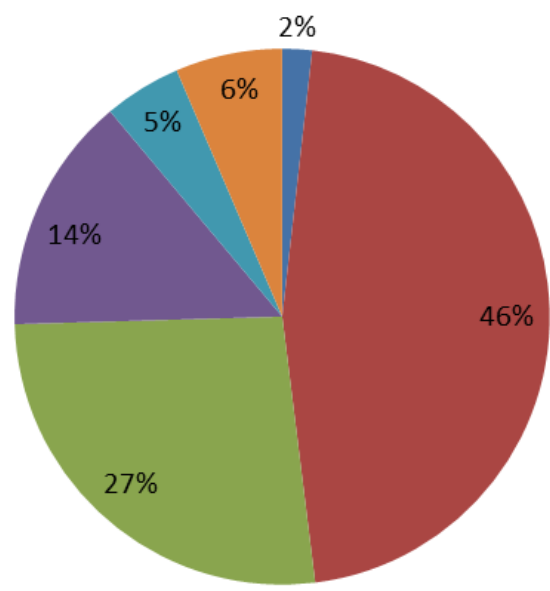

Fig. 2. Level of use in academic activities

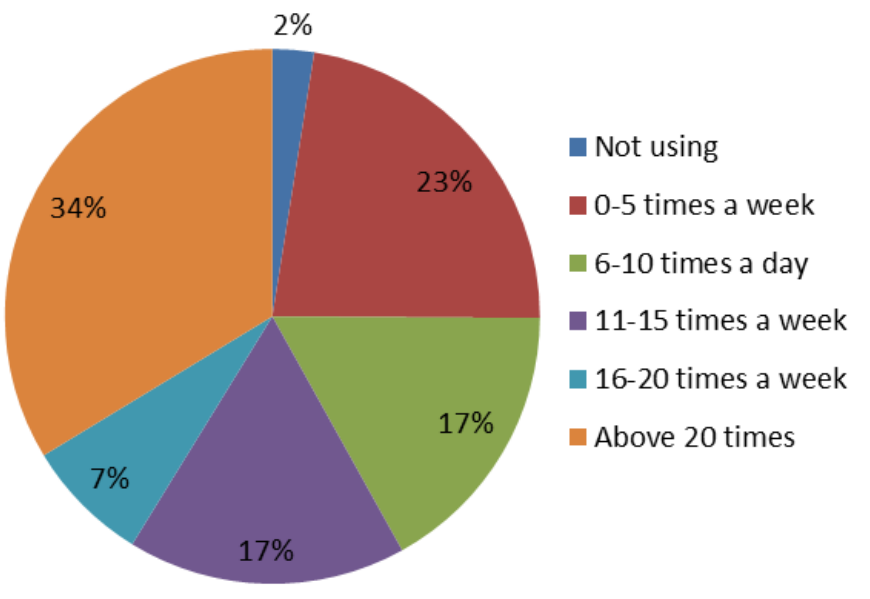

Fig. 3. Level of use for social activities

Inferential statistical analysis in the form of correlation analysis was used to evaluate the relationships between variables, therefore testing the hypotheses of this study (see the conceptual model at Fig. 1). The correlation formula is given as: 
$\rho X, Y=\operatorname{corr}(X, Y)=\frac{\operatorname{cov}(X, Y)}{\sigma_{X} \sigma_{Y}}=\frac{E\left[\left(X-\mu_{X}\right)\left(Y-\mu_{Y}\right)\right]}{\sigma_{X} \sigma_{Y}}$

where $\mathrm{x}$ is one variable, e.g. motivation to use and $\mathrm{y}$ another, e.g. behavioural intention; and $\rho X, Y$ is the correlation coefficient.

Kendall tau rank correlation coefficients were used because we do not have absolute values [30]. Tables 3 is a summary of relationships between variables and links the relationships to hypotheses presented previously in the model. Correlations marked with a single asterisk are significant at level 0.05 and those with double asterisks are significant at level 0.01 . The absence of an asterisk indicates no correlation and this is the case in motivation to use and behavioural intention. The rest of this section will discuss each pair of variables before a general summary of the findings and implications are presented.

\section{Discussion}

Table 3 is a correlation table from the data collected from Scotland and Nigeria, it shows that all the relationships examined in the model were significant except motivation to use in the Nigerian data.

This research validates the constructs: perceived usefulness, performance expectancy, perceived ease of use, prior knowledge, motivation, facilitating conditions, and social factor from TAM, UTAUT and TRA [2][8][18] and also validate the new construct prior knowledge. The correlation between behavioural intention (BI) and perceived usefulness (PU) in Scotland data and Nigeria is highly significant and reaches the value of .616 and .549 , respectively. That means that there is a relationship between acceptance and usefulness in the case of Web 2.0 technologies. The rest of this section will discuss the relationships between $\mathrm{BI}$ and other variables.

Table II. GENERAL CORRELATION BETWEEN BEHAVIOUR INTENTION AND OtHER CONSTRUCTS

\begin{tabular}{|c|c|c|c|c|c|c|}
\hline \multirow{2}{*}{$\begin{array}{l}\text { Dependent } \\
\text { Variable }\end{array}$} & \multirow[t]{2}{*}{ Independent Variable } & \multicolumn{2}{|c|}{ Correlations Coefficients } & \multicolumn{2}{|c|}{ Significance } & \multirow[t]{2}{*}{ Hypothesis } \\
\hline & & Scotland & Nigeria & Scotland & Nigeria & \\
\hline BI & TAM (PU) & $.616^{* *}$ & $.549^{* *}$ & Yes 0.01 & Yes 0.01 & $\mathrm{H}_{1}$ \\
\hline $\mathrm{BI}$ & TAM, UTAUT (SF) & $.674^{* *}$ & $.520^{* *}$ & Yes 0.01 & Yes 0.01 & $\mathrm{H}_{2}$ \\
\hline BI & Mine (PK) & $.625^{* *}$ & $.153^{*}$ & Yes 0.01 & Yes 0.05 & $\mathrm{H}_{3}$ \\
\hline $\mathrm{BI}$ & UTAUT (FC) & $.130^{*}$ & $.115^{*}$ & Yes 0.05 & Yes 0.05 & $\mathrm{H}_{4}$ \\
\hline $\mathrm{BI}$ & TAM (PEoU) & $.221^{* *}$ & $.134^{*}$ & Yes 0.01 & Yes 0.05 & $\mathrm{H}_{5}$ \\
\hline $\mathrm{BI}$ & UTAUT (PE) & $.620^{* *}$ & $.431^{* *}$ & Yes 0.01 & Yes 0.01 & $\mathrm{H}_{6}$ \\
\hline $\mathrm{BI}$ & MtU (TRA) & $.290^{* *}$ & .932 & Yes 0.01 & No & $\mathrm{H}_{7}$ \\
\hline $\mathrm{AU}$ & TAM, UTAUT (BI) & $.155^{*}$ & $.189^{*}$ & Yes 0.01 & Yes 0.01 & $\mathrm{H}_{8}$ \\
\hline
\end{tabular}

Figures 2 and 3 show the percentage of academic and social uses, respectively. We observe that the percentage of academic use per week is very low (0-5) for majority of users and social purpose use is as high as 20 times and above for majority of users.

Table 3 also shows the relationship between Behavioural Intention and Performance Expectancy as highly significant for Scotland and Nigeria $\left(.620^{* *}, .431^{* *}\right)$ at 0.01 level of significance. This is in agreement with existing research [8] that there is a relationship between acceptance and performance expectancy. The correlation between Behaviour Intention and Social Factor is highly significant $\left(.674^{* *}\right.$ and $.520^{* *}$ at 0.01 level of significance. This also agrees with previous research [8][2] meaning there is a relationship between social factor and intention to use Web 2.0 technologies for learning.

The correlation between behavioural intention and actual use is significant at 0.05 level in the two economies. This is in line with the technology acceptance model [2][8][33[34]. There is correlation between behavioural intention and motivation (MtU) in Scotland at 0.05 level of significance (see Table 3) and this agrees with the research by Ajzen and Fisnbein [18]. However, MtU is not significant in Nigeria and the reason was that learning management systems (LMS) are rarely available in Nigerian universities, hence the need for more research in this area when LMS are more available in Nigeria.
The relationship between behavioural intention and perceived ease of use is highly significant in Scotland at 0.01 level, but just significant at 0.05 level in Nigeria. However this agrees with other research [2][35] that ease of use influences behavioural intention, meaning that there is a relationship between perceived ease of use and behavioural intention. The table also shows that there is a significant correlation between behavioural intention and facilitating conditions, meaning that there is a relationship between these two variables and this agrees with other research [8][11][20].

On the whole, this research has validated the conceptual model (Figure 1), it agrees with other research $[2][3][4][8][18][11][20]$ and also unveils a new construct, prior knowledge, which has a positive relationship with behavioural intention which should explain acceptance of Web 2.0 tools for learning.

\section{CONCLUSIONS, IMPLiCATIONS AND AREAS For FURTHER STUDY}

This research examined user acceptance and adoption of Web 2.0 technology tools for learning among populations in Nigeria and Scotland. It aimed to give insight into the very low use of these tools and to proffer key related factors that should be borne in mind by policy makers and system developers who aim to encourage increased use of these tools in teaching and learning. The research has validated its conceptual model. It 
has also revealed low motivation in Nigeria to the use these tools for academic purposes. A casual observation suggests that this is caused by inadequate provision of learning management systems (LMS) with social media tools. Thus, future research should investigate in Nigeria or a similar developing country motivation to use Web 2.0 tools when learning management systems (LMS) with social media are popular in such environments. Besides, a qualitative approach should be used to complement the quantitative findings of this research. It is also the intent of the researcher to set up an experimental use of LMS with social media in some of these institutions in Nigeria to further validate this work as well as discover implementation issues.

This work contributes to the body of knowledge on factors that affect acceptance and use of Web 2.0 social networking technology tools in teaching and learning. This will aid management decisions towards enhancing and improving educational experience as they consider the key variables validated in this research.

\section{REFERENCES}

[1] E. Swanson. (1994). Information Systems Innovation among Organizations, Management Science, Vol. 40, No. 9, 1069-1092.

[2] F. Davis, R. Bagozzi and P. Warshaw (1989). User Acceptance of Computer Technology: a comparison of two theoretical models. Management Science, Vol. 35, pp. 982 - 1003.

[3] V. Venkatesh and F. Davis, (2000). A Theoretical Extension of the Technology Acceptance Model: four Longitudinal Field Studies. Management Science, Vol. 46, No. 2, pp. 186-204.

[4] V. Venkatesh, M. Morris, G. Davis, and F. Davis, (2003). User acceptance of information technology: Toward a unified view, MIS Quarterly, Vol. 27(3) pp. 425-478.

[5] L. Oshiyanki, P. Cairns, and H. Thimbleby, (2007). Validating Unified theory of acceptance and use of Technology (UTAUT) tool crossculturally. British computer society, Vol. 2 Proceedings of the $21^{\text {st }}$ century BCS group conference.

[6] C. Anunobi and A. Ogbonna (2012). Web 2.0 Use by Librarians in a state in Nigeria, Developing Country Studies, Vol. 2, No. 5, pp. 7-66, 2012.

[7] R. Echeng (2011). The use of Web 2.0 in teaching and learning in Nigerian higher institution, An MSc Thesis submitted to the School of Computing, University of the West of Scotland.

[8] H. Ajjan and R Hartshorne (2008). Investigating faculty decisions to adopt Web 2.0 technologies: Theory and empirical tests, The Internet and Higher Education, Vol. 11, No 2, pp. 71-80, 2008.

[9] G. Baxter, M. Stansfield, and T. Connolly (2011). Introducing Web 2.0 in education: A structured approach adopting a Web 2.0 implementation framework. Next Generation Web Services Practices (NWeSP), 2011 7th International Conference on 19-21 Oct. 2011, 499 - 504.

[10] R. Echeng, A. Usoro and G. Majewski, (2013). Acceptance of Web 2.0 in Learning in higher education: an empirical study of a Scottish university, WBC July Conference Proceedings on E-learning.

[11] P. Jucevičienè, G. Valinevičienè,(2010). A Conceptual Model of Social Networking in Higher Education, Electronics and Electrical Engineering - Kaunas: Technology, vol. 6, no. 102, pp. 55-58.

[12] C. Ennew, A. Fernandez-Young (2006). Weapons of mass instruction? The rhetoric and reality of online learning, Marketing Intelligence \& Planning, Vol. 24 Issue: 2, pp.148 - 157.

[13] J. Njenga and, L Fourie (2010). The myths about e-learning in higher education British Journal of Educational Technology Vol. 41 No. 2, pp. $199-212$.

[14] C. Redecker, Review of Learning 2.0 practices, Study on the Impact of Web 2.0 Innovations on Education and Training in Europe, 2009 Available online https://europa.eu/Publications/pub.cfm?id=2059 [Accessed: 25-11-2011].

[15] T. Franklin and M. Van Harmelen (2007). Web 2.0 for content for learning and teaching in higher education, London: Joint Information Systems Committee, 2007. JISC www. jisc. ac. uk/media/documents/programmes/digitalrepositories/web2
[16] B. Alexander, Web 2.0: A new wave of innovation for teaching and learning? EDUCAUSE Review, Vol. 41, no. 2, pp. 32-44, 2006.

[17] T. Valtonen, S. Hacklin, S. Kontkanen, ,A. Hartikainen-Ahia, S Kärkkäinen and Kukkonen, J. (2013). Pre-service teachers' experiences of using social software applications

for collaborative inquiry, Computers \& Education 69 (2013) 85 - 95.

[18] I. Ajzen and M. Fishbein, Understanding attitudes and predicting social behavior, Englewood Cliff, NJ: Prentice Hall, 1980.

[19] J. Armitage, and M. Connor (2010). Efficacy of theory of planned behaviour. British Journal of Social Psychology (2001), 40, 471-499.

[20] S. Mazman, and Y. Usluel, (2010). Modeling educational usage of Facebook. Computers \& Education, Vol.55, pp. 444-453.

[21] Echeng, R., Usoro, A., Majewski, G. (2013). Acceptance of Web 2.0 in Learning in higher education: an empirical study of a Scottish University, WBC 2013 July conference proceedings on e-learning, pp. 30-38.

[22] N. Fielding and R. Lee (1998). Computer Analysis and Qualitative Research. SAGE publications.

[23] B. Guerin (1993). Social Facilitation. Cambridge, England: Cambridge University press.

[24] S. Taylor, \& Todd, P. A. (1995) Understanding information technology usage: A test of competing models. Information systems research, 6(2), 144-176.

[25] J. Aiello and E. Douthitt (2001) Social Facilitation from Triplett to Electronic Performance Monitoring Group Dynamics. Theory, Research and Practice, Vol. 5, No 3, pp. 163-180.

[26] S. Kujawa and L. Huske (1995). The Strategic Teaching and Reading Project guidebook Oak Brook, IL: North Central Regional Educational Laboratory.

[27] T. Mitchell, S. Chen, and R. Macredie (2005). Hypermedia learning and prior knowledge: domain expertise vs. system expertise Journal of Computer Assisted Learning Vol. 21(1). pp. 53-64.

[28] Eccles, J. and Wigfield, A. (2002). Annual Review in Psychology, Vol. 53, pp.109-132.

[29] M. Fetscherin, and C. Lattemann (2008). User Acceptance of Virtual Worlds.Journal of electronic commerce research, Vol. 9, No. 3, pp. 231241.

[30] G. Zikmund Business Research Methods, Mason, OH: Thomson/South Western, 2003.

[31] O'Cathain, A., Murphy E, Nicholl J (2010). Three Techniques for integrating data in mixed methods studies. BMJ 2010;341:c4587.

[32] V. Terzis, A. Economides (2011). The Acceptance and Use of Computer Based Assessment. Computers \& Education, Vol. 56, pp. 1032 - 1044.

[33] T. Alrawashdeh, M. Muhairat, and S. Alqatawnah (2012). Factors Affecting Acceptance of Web-Based Training System: Using Extended UTAUT and Structural Equation Modeling. International Journal of Computer Science, Engineering and Information Technology (IJCSEIT), Vol. 2, No.2, pp. 45-54.

[34] D. Straub, M. Keil, and W. Brenner (1997) Testing the Technology Acceptance Model Across cultures: A Three Country Study. Information and Management, Vol. 33, No.1, pp. 1 - 11.

AUTHORS' PROFILE

Razep Echeng is a PhD research student at the University of the West of Scotland and also an associate lecturer teaching oracle database and design with SQL and software project management tutorials. She has a first degree in Computer Science from the University of Calabar, Nigeria and a master's degree in advanced computer systems development at the University of the West of Scotland. Her research is on e-learning with the use of Web 2.0 social media tools for learning. She has published six conference and journal articles in this area and written one book chapter. She is also interested in analysing and designing e-learning systems.

Dr Abel Usoro lectures and researches in information systems in the School of Computing, University of the West of Scotland. He has published widely in refereed journals, conferences and book chapters. He has served in the scientific committee of a few conferences two of which he has chaired. $\mathrm{He}$ is the lead editor of Leveraging Developing Economies with the Use of Information Technology: Trends and Tools (http://www.igiglobal.com/book/leveraging-developing-economies-use-information/61661). His current research interest are knowledge management and e-learning. $\mathrm{He}$ has graduated three $\mathrm{PhDs}$ and also acts as director of studies to a few research students. 